\title{
Understanding Oil Palm Smallholders' Behavioral Intention on Sustainable Production Practices
}

\author{
Eko Ruddy Cahyadi* \\ Departement of Management, Faculty of Economics and Management, IPB University \\ e-mail: ekocahyadi@apps.ipb.ac.id \\ Fitri Yutika \\ Departement of Management, Faculty of Economics and Management, IPB University \\ e-mail: yutikasihombing@gmail.com \\ Heti Mulyati \\ Departement of Management, Faculty of Economics and Management, IPB University \\ e-mail: heti@apps.ipb.ac.id
}

\begin{abstract}
While smallholders play a significant contribution on Indonesian oil palm production, they are confronted to sustainability challenges. This study aims to analyze determinants of their behaviour to apply sustainable practices. Theory of Planned Behavior was applied to examine the effect of attitudes, subjective norms, perceived behavioral control and past behavior toward smallholders' intention to implement sustainable oil palm production practices. In this study the sustainable practices include applying organic fertilizer, integrated pest management, non-fire land clearing, certified seed and participating in a farmer group. A survey was carried out over 242 oil palm smallholders in Kampar, Riau. Structural Equation Modeling (SEM) with Partial Least Square (PLS) program was employed to examine our hypothesis. The results show that attitudes, perceived behavioral control and past behavior have positive and significant effects on smallholders' intention to implement sustainable production practices, whereas subjective norms seems to be not significant. Smallholders tend to be individually independent in making a decision or taking action. Hence, improving attitude toward sustainability, for example, through extension service or training and providing incentives to overcome perceived behavioural control are expected to be an effective measure to encourage sustainability practices among oil palm smallholders.
\end{abstract}

Keywords: intention, oil palm smallholders, sustainable practices, theory of planned behaviour. 


\section{INTRODUCTION}

Oil palm commodity has an important role in the development of Indonesia's economy. According to the National Trade Ministry data, palm oil is the largest foreign exchange earner in the non-oil sector (DITJENBUN, 2017). Indonesian Palm Oil Association (GAPKI) states that Indonesia is a producer and exporter of palm oil in the world (GAPKI, 2017). In addition, oil palm plantations as a source of income and improve living standards of farmers, a source of jobs, and enhance the development of the region (Afifuddin \& Kusuma, 2007). Along with these positive contributions, today's Indonesian palm oil industry is faced with the issue of sustainability is a challenge for all players in the supply chain. According to the Palm Oil Agribusiness Strategic Policy Institute (PASPI), Anti-palm oil Non Governmental Organization (NGO) running a negative campaign against the Indonesian palm oil industry. The campaign influence the opinion of all supply chain ranging from consumers, manufacturers, industrial and governments. The sustainability issues may hamper oil palm commodity market access in international market [16]

RSPO (Roundtable Sustainable Palm Oil) and ISPO (Indonesian Sustainable Palm Oil) certification are a standard and sustainable global parameters for palm oil products. RSPO and ISPO had Principles \& Criteria (P \& C), which focuses on the legal, economic, environmental and social needs for sustainable palm oil production. In the P \& C RSPO and ISPO, there are cultivation techniques and good management of oil palm (Good Agriculture Practices / GAP), which can support sustainable palm oil development economically, socially and environmentally (PASPI, 2016). Land clearing without burning, use of organic fertilizers, pest control organically (OPT), using certified seed, following farmer groups, and using conflict-free land is part of sustainability practices in GAP.

Indonesian Oil palm plantations according to concession status cultivated by smallholders as much as 42.3 percent. Based on data from the Directorate General of Plantation, smallholder plantation area has increased every year (DITJENBUN, 2017) and will continue to increase become the owner of the largest share of palm oil entrepreneurship in Indonesia. This is due to increasingly limited land relatively widespread in Indonesia, so it will limit the space for a large company to expand the land area (GAPKI, 2017).

Kampar Regency is an area of palm oil production centers in Riau Province which is dominated by smallholders with 196.991 hectares wide. Kampar Regency also has the largest labor force farmers (85.405 households) compared to other districts in Riau Province (DITJENBUN, 2017). However, the plantation area and many farmers do not guarantee the oil palm plantation productivity in Kampar Regency. The productivity of oil palm cultivated by smallholders in Kampar is lower (2,05 tons / ha) than other districts in Riau Province (DITJENBUN, 2017).

Smallholder plantations cultivated by independent farmers and plasma farmers pattern. Plasma plantations are collaborative programs between farmers and private companies or state companies. The core company build and develop plasma plantations input supply, providing technical guidance in business management, control and improvement of the necessary technology for increased efficiency and productivity of businesses (SPKI, 2009). Meanwhile, an independent farmers with their own initiative and cost of opening and managing the land, is not associated with a particular company (Ansoko \& Widodoro, 2013). Independent farmers do not have KUD institutions and farmer groups at all, which is caused by weak guidance by agencies and due to the absence of pure oil palm planters (Hadi, Rifai, \& Qomar, 2009).

Smallholders as upstream supply chain actors have an important role in creating an integrated supply chain system in addressing the issue of sustainability and increase productivity. The decision of farmers to implement sustainable practices based on the motives and complex considerations, which not only deals with the economic aspects but more psychological (Hansson, Ferguson, Olofsson, \& Rantamäki-Lahtinen, 2013). Ajzen and Fishbein (2005) argued the Theory of Planned Behavior (TPB) that was explaining human action is guided by three kinds of factors, namely (1) belief about the results of the behavior and evaluate the results of the behavior (behavior belief), (2) beliefs about the normative expectations of others and motivation to comply 
with the expectations of their (normative belief), and (3) beliefs about the presence of factors that facilitate or inhibit behavior, as well as perceptions of power in these factors (control belief) (Ajzen \& Fishbein, 2005).

Smallholders intention toward sustainability can be predicted using TPB for its ability to handle complex behavior which describes the mechanisms that make people support the practices of sustainable (Yazdanpanah, Hayati, Hochrainer-Stigler\& Zamani, 2014; Menozzi, Fioravanzi, \& Donati, 2015; Terano, Mohamed, Shamsudin, \& Latif, 2015; Zeweld, Van Huylenbroeck, Tesfay, \& Speelman, 2017; Wiradmadja, 2017). In addition, when a person is unable to access the attitude, then past behavior is a predictor for subsequent behavior (Dharmmesta, 2000). The behavior of the past can be used as a predictor of behavior intention to affect the individual, but it also can weaken the intention to behave (Aikanatha, Chenayah, \& Sasekumar, 2016). This study aimed to analyze the influence of attitude, subjective norm, perceived behavioral control and past behavior on the farmers intention to do sustainable production practices in Kampar Regency.

\section{RESEARCH METHODS}

This research was conducted on oil palm smallholder in Kampar regency, Riau. Kampar regency is a center for producing palm oil which is dominated by smallholder plantations, with the largest number of farm laborers and the lowest productivity level in Riau province. The research used primary data and secondary data. Primary data was obtained by conducting face to face interview using questionaires with 242 respondents. Meanwhile secondary data was obtained from the literature or references which related to this research. The variables in this research used the Theory of Planned Behavior (TPB) (Ajzen \& Fishbein, 2005) and TPB modification (Menozzi, Fioravanzi, \& Donati, 2015). The independent variable (X) consists of attitudes towards sustainability (X1), subjective norms (X2), perceived behavioral control (X3) and past behavior (X4), and the dependent variable (Y) namely intention (Y1) to implement sustainable palm oil production practices. Data processed by using Microsoft Office Excel 2013 and Smart Partial Least Square (PLS) software. The data analysis technique used in this research were descriptive statistical analysis and Structural Equation Modeling (SEM).

\section{RESULTS AND DISCUSSION}

\section{Characteristics of Respondents}

Age is one of the factors that affect work productivity. The economically productive age is divided into 3 groups, namely the non-productive age group (0-14 years), the productive age group (15-65 years), and the no longer productive age group ( $>65$ years). Table 2 shows that respondents were in productive age, with an average 48,68 years. This means that respondents are potential enough to carry out their farming activities in a sustainable manner. Education level of respondents are elementary school graduates, with an average length of education of 8,35 years. Farmers respondents have low education levels, this shows that farmers do not have extensive knowledge and insights from formal education. Most of the respondents' income sources are from oil palm farming, with an average 84 percent of oil palm plantation. Additional sources of income for smallholders are stalls or shop trading businesses, fishermen, company employees, and casual daily laborers.

Table 1 shows that the average respondent's plantation area is 3,97 hectares. The minimum business scale for smallholder oil palm plantations is 2 to 4 hectares (DITJENBUN, 2017). It means, respondents have enough plantation area to meet the input production needs and the livelihood needs of farmers. The average yield of the respondent's oil palm plantation is 1,66 tons per hectare. This shows that the palm oil productivity of the respondent is still low compared to their actual potential, in accordance with the vision 35-26 launched by the government at the 100th anniversary of the Indonesian palm oil industry in 2011. All respondent farms recorded were harvested area, with an average of oil palm age 20,04 years. This shows that respondents has oil palm at an economic age ( $<25$ years). 
Table 1. Basic characteristics of respondent and production characteristics

\begin{tabular}{lccc}
\multicolumn{1}{c}{ Characteristics } & Min-Max & Mean & Standart Deviation \\
\hline Age (year) & $22-75$ & 48,68 & 10,40 \\
Education (year) & $0-18$ & 8,35 & 4,15 \\
Income from oil palm (\%) & $30-100$ & 84,29 & 19,16 \\
Plantation area (ha) & $0,5-50$ & 4.95 & 6,06 \\
Yield (tons/ha) & $0,4-3$ & 1,54 & 0,41 \\
Oil palm age (year) & $5-28$ & 17,88 & 5,06 \\
\hline
\end{tabular}

Source: Data processed (2019)

\section{Smallholders' Intention on Sustainable Oil Palm Production Practices}

Outer model analysis is a measurement used to test the validity and reliability of research indicators. Outer model analysis is done by testing convergent validity (loading factor $>0,50$ ), discriminant validity $(\mathrm{AVE}>0,50)$, and composite realiability (composite realiability $>0,70$ ). Table 2 shows that the variables and indicators in the research model are valid and reliable, and can proceed to the Inner Model Analysis stage.

Table 2 shows that respondents' attitude toward sustainability belong to the three top boxes. This means that respondents have a positive attitude toward the importance of implementing sustainability practices. Subjective norms of the extension program respondents are very low. This happened because the respondent had never received an extension program from anyone. Nevertheless, respondents have a high desire to do what people around them do (other farmers, oil palm companies and extension workers) if it is proven to increase the palm oil productivity. Respondents have a high perception that doing sustainability practices will cost more, time, and knowledge. Respondents have limited costs for conducting land crearing without burning $(3,72)$, buying organic fertilizer $(4,03)$, buying certified biofuels $(4,55)$, paying for plantation management fees through farmer groups $(4,50)$, and buying conflict free land $(3,96)$. In addition, there is limited time to do land crearing without burning $(4,63)$ and limited knowledge to distinguish authentic and fake certified seeds $(3,53)$. Respondents have not implemented sustainability practices well in the past, such as using organic fertilizers $(4,09)$ and organic pest control $(2,47)$. Then, respondents have a low intention to do pest control manually and organically. In addition, the intention to use organic fertilizers and certified seeds is high.

Table 2. Test results of Validity and reliability variables and indicators

\begin{tabular}{|c|c|c|}
\hline Variables* & Indicators** & Mean (SD) \\
\hline \multirow[t]{5}{*}{$\begin{array}{l}\text { Attitude toward } \\
\text { sustainability }\end{array}$} & $\begin{array}{l}\text { Preventing and protecting oil palm plants from pests, diseases and weeds can } \\
\text { be done by manual and organic materials }\end{array}$ & $6,28(1,14)$ \\
\hline & $\begin{array}{l}\text { Following farmer groups can get a lot of useful information about oil palm } \\
\text { cultivation }\end{array}$ & $5,33(1,79)$ \\
\hline & $\begin{array}{l}\text { Environmental sustainability can improve the safety, comfort and health of } \\
\text { palm oil farmers in a sustainable manner }\end{array}$ & $5,79(0,92)$ \\
\hline & $\begin{array}{l}\text { Palm oil plants that are free of plant pest organisms (pests, diseases and } \\
\text { weeds) can increase productivity }\end{array}$ & $6,49(0,61)$ \\
\hline & Using disputed land can cause losses and to lose oil palm plantations & $6,71(0,47)$ \\
\hline \multirow[t]{9}{*}{ Subjective norm } & Extension agents recommend not burning the land & $1,76(1,08)$ \\
\hline & Extension agents recommend using organic fertilizer & $1,56(0,75)$ \\
\hline & $\begin{array}{l}\text { Extension agents recommend controlling pests, diseases and weeds using } \\
\text { manual tools and organic materials }\end{array}$ & $1,52(0,63)$ \\
\hline & Extension agents recommend using certified seeds & $1,48(0,50)$ \\
\hline & Extension agents recommend that they join farmer groups & $1,48(0,50)$ \\
\hline & Extension agents recommend using conflict free land & $1,48(0,50)$ \\
\hline & $\begin{array}{l}\text { Doing what other farmers do, if it is proven to increase the productivity of } \\
\text { palm oil }\end{array}$ & $6,56(0,59)$ \\
\hline & $\begin{array}{l}\text { Doing what oil palm companies do, if it is proven to increase palm oil } \\
\text { productivity }\end{array}$ & $6,64(0,57)$ \\
\hline & $\begin{array}{l}\text { Do what is recommended by the extension program, if it is proven to increase } \\
\text { the productivity of palm oil }\end{array}$ & $6,38(0,67)$ \\
\hline \multirow{3}{*}{$\begin{array}{l}\text { Perceived } \\
\text { behavioral control }\end{array}$} & Manually clearing land or using heavy equipment (steking) will cost more & $6.41(0,66)$ \\
\hline & $\begin{array}{l}\text { Manually cleaning land or using heavy equipment (steking) spends more } \\
\text { time }\end{array}$ & $5.23(1,18)$ \\
\hline & Making organic fertilizer requires knowledge & $5.52(1,13)$ \\
\hline
\end{tabular}




\begin{tabular}{lll}
\hline \multicolumn{1}{c}{ Variables* } & \multicolumn{1}{c}{ Indicators** } & Mean (SD) \\
\hline & $\begin{array}{l}\text { Pest, disease and weed control using organic materials and manual tools } \\
\text { requires knowledge }\end{array}$ & $5,52(1,13)$ \\
& $\begin{array}{l}\text { Following the pattern of farmer groups will reduce income from oil palm } \\
\text { Have money to open new land by means and manual tools without burning }\end{array}$ & $6,41(0,66)$ \\
& Have time to manually manage new land without burning & $4,63(1,48)$ \\
& Have money to buy organic fertilizer & $4,03(1,53)$ \\
& Have money to buy certified seeds & $4,55(1,41)$ \\
& Have the knowledge to distinguish authentic and fake certified seeds & $3,53(1,87)$ \\
& Have money to pay for the costs of managing oil palm plantations together & $4,50(1,63)$ \\
& with farmer groups & $3,96(1,37)$ \\
\hline Pave money to buy conflict free land & $4,09(2,21)$ \\
& Using organic fertilizer in the last 3 years & $2,47(1,17)$ \\
& $\begin{array}{l}\text { Controlling plant pest organisms (pests, diseases and weeds) organically in } \\
\text { the last 3 years }\end{array}$ & \\
\hline Intention & $\begin{array}{l}\text { Respondents intend to use organic fertilizer from the next period and reduce } \\
\text { chemical fertilizers }\end{array}$ & $5,36(1,65)$ \\
& $\begin{array}{l}\text { Respondents intended to use manual tools and organic materials to control } \\
\text { pests, diseases and weeds from the next period and reduce the use of } \\
\text { chemical poisons }\end{array}$ & $3,87(1,92)$ \\
& $\begin{array}{l}\text { Respondents intend to use certified seeds when replanting or opening new } \\
\text { gardens }\end{array}$ & $6,00(1,37)$ \\
\hline
\end{tabular}

Source: Data processed (2019); *Reliable (composite realiability $>0,70$ ); **Valid (loading factor $>0,50$ )

The results test using PLS-SEM shows the value of $\mathrm{R}^{2}$ for the intention variable is 0,55 , it means that all independent variables can explain and affect the intention to adopt sustainable production practices by 55 percent, the remaining 45 percent is explained by other variables outside the research model. Then, testing path coefficients to see the relationship between construct variables. The $t$-statistic value is more than 1,96 with alpha 5 percent indicating there is influence between construct variables. Figure 1 shows the results of testing path coefficient.

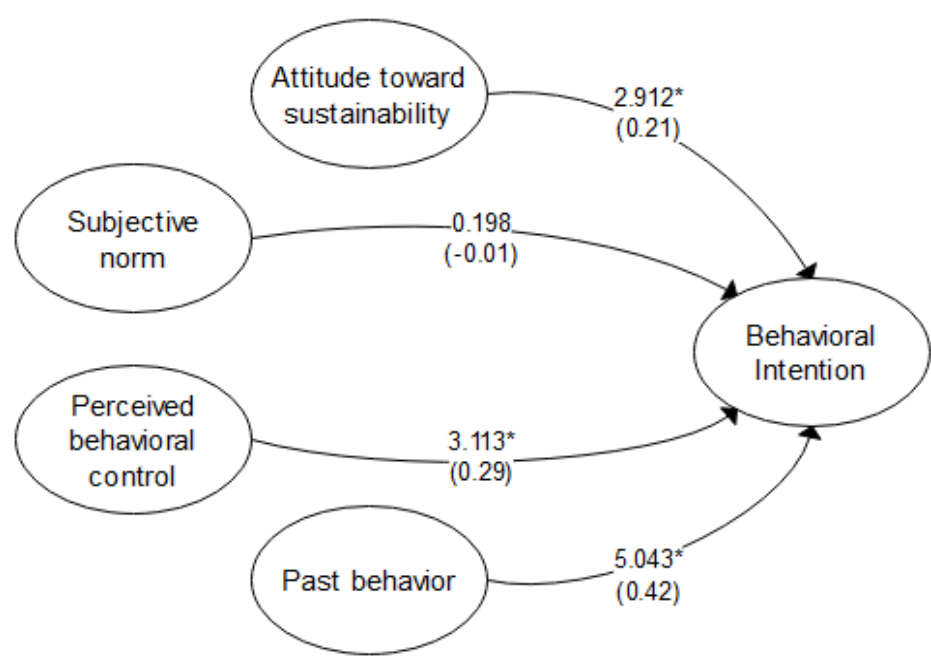

Figure 1. The results of path coefficients: T-statistict (Original Sample) Source: Data processed (2019); *Significant at the t-statistic > 1.96 alpha 5\% 
Perceived behavioral control affect smallholders' intention to implement sustainable production practices significantly (t-statistics $3.11>1.96$ ). It means that along with the increasing perception of behavioral control it increases smallholders' intention to implement sustainable production practices. Smallholder realize that the behavior of implementing sustainability practices requires much money, time and knowledge. Making organic fertilizer independently requires much knowledge. Based on research data, smallholders lack the knowledge to make organic fertilizer independently, but smallholders try to buy ready-made organic fertilizers, such as empty bunches from the rest of the processing in palm oil mills and the ash from empty fruit bunches. Controling of pests, diseases and weeds organically also requires more knowledge about tools, materials and how to make them. Quality seeds will produce more fruit, heavier and fuller and avoid male oil palm seeds. Certified oil palm seedlings are more expensive and can be obtained with official purchases from companies that are recognized by the government and certified by the authorized institutions. Although expensive, smallholders are trying to buy and use certified seeds in the future to increase oil palm production. The stronger the behavioral controlling factors, the higher the intention of respondent farmers to implement sustainable production practices. This finding is supported by Menozzi, Fioravanzi, \& Donati (2015); Terano, Mohamed, Shamsudin, \& Latif (2015); Zeweld, Van Huylenbroeck, Tesfay, \& Speelman (2017) that the intention to carry out sustainable agricultural practices is influenced by behavioral control perceptions.

Past behavior affect smallholders' intention to implement sustainable production practices significantly (t-statistics 5.04>1.96). Past behavior is the dominant predictor of all variable that influenced smallholders' intention. The result shows that good past behavior can increase smallholders' intention to implement sustainable production practices. Past behavior reflects the habits of smallholders in their oil palm production activities in the past. Based on research data, the application of sustainable production practices is still not good in the practice of using organic fertilizers and pest control organically. Smallholders tend to prefer to use chemical fertilizers because they are easier to obtain, easy and quickly applied to oil palm plantations. In general, the existence of pests and diseases in oil palm plants is not realized by smallholders. Smallholders consider this not a problem, so there is no further handling. Eradication of weeds is also more often done by spraying chemical poisons. This is what causes smallholders to have a low intention to use fertilizers and control the pest organically in the future. This finding is supported by the research of Menozzi, Fioravanzi, \& Donati (2015) which analyzed the motivation of farmers in adopting GAP, ie past behavior influenced farmers' intention to implement a behavior. When a person is unable to determine an attitude, then the habits of the past will be carried out in the future (Dharmmesta, 2000).

Subjective norm is not a significant predictor of smallholders' intention to implement sustainable production practices significantly (t-statistic $0.19<1.96$ ). Based on research data, extension programs do not play a role in creating respondents' intention to implement sustainable production practices. This finding is in line with the research of Menozzi, Fioravanzi, \& Donati (2015); Terano, Mohamed, Shamsudin, \& Latif (2015) that the intention to practice sustainable agriculture is not influenced by individual subjective norm.

\section{Managerial Implications}

Improving attitudes towards sustainability and perception of behavioral control can increase smallholders' intentions to adopt sustainable practices. Farmers recognize that applying sustainable production practices require more cost, more time, and a higher knowledge. To overcome the limitations of cost, farmers should look for other sources of income to support the maintenance costs of sustainable palm oil. Efforts to increase this income can be done by utilizing oil palm plantations as a farm, it simultaneously supports the procurement of manure and minimize weeds. While time constraints can be overcome if you have enough money to use technology and additional aid workers. While the lack of knowledge can be supported by the existence of informal education such as education and socialization programs through the mass 
media (television, social media, newspapers, etc.), this will also increase the awareness and attitudes of smallholders towards sustainability.

\section{CONCLUSIONS}

Attitudes toward sustainability, perceived behavioral control and past behavior has a significant influence on smallholders' intention to implement sustainable production practices. Conversely, subjective norm has no influence on the intention of farmers to adopt sustainable production practices. Improving attitudes towards sustainability and perception of behavioral control can increase smallholders' intention to adopt sustainable practices.

\section{REFERENCES}

[DITJENBUN] Direktorat Jenderal Perkebunan. (2017). Statistik Perkebunan Indonesia 20152017: Kelapa Sawit. Kementerian Pertanian. Available at:http://ditjenbun.pertanian.go.id/tinymcpuk/gambar/file/statistik/2017/Kelapa-Sawit 2015-2017.

[GAPKI] Gabungan Pengusaha Kelapa Sawit Indonesia. (2017). Sawit dan Kebijakan Industrialisasi menuju 2050. Available at: https://gapki.id/ news/3209/sawit-dankebijakan-industrialisasi-sawit-menuju-2050.

Afifuddin, S., \& Kusuma, S. I. (2007). Analisis Struktur Pasar CPO: Pengaruhnya terhadap pengembangan ekonomi wilayah Sumatera Utara. Jurnal Perencanaan dan Pengembangan Wilayah, 2(3), 124-136.

[SPKI] Serikat Petani Kelapa Sawit Indonesia. (2009). Saatnya Memajukan Kepentingan Nasional dan Kemakmuran Rakyat Tani. Jakarta: Serikat Petani Indonesia.

Andoko, A., \& Widodoro. (2013). Berkebun Kelapa Sawit si Emas Cair. Jakarta: PT Agro Media Pustaka.

Hadi, S., Rifai, A., \& Qomar, N. (2009). Industri Kelapa Sawit Rakyat di Riau Membangun Kemandirian Petani. Pekanbaru: UNRI Press.

Hansson, H., Ferguson, R., Olofsson, C., \& Rantamäki-Lahtinen, L. (2013). Farmers' motives for diversifying their farm business-The influence of family. Journal of Rural Studies, 32, 240250.

Ajzen, I., \& Fishbein, M. (2005). The influence of attitudes on behavior. In Albarracin, D, Johnson, BT, Zanna MP. (Eds), The handbook of attitudes, Lawrence Erlbaum Associates.

Yazdanpanah M, Hayati D, Hochrainer-Stigler S, Zamani GH. 2014. Understanding farmers' intention and behavior regarding water conservation in the Middle-East and North Africa: A case study in Iran. Journal of Environmental Management. 135, 63-72.

Menozzi, D., Fioravanzi, M., \& Donati, M. (2015). Farmer's motivation to adopt sustainable agricultural practices. Bio-based and Applied Economics, 4(2), 125-147, doi: 10.13128/BAE-14776.

Terano, R., Mohamed, Z., Shamsudin, M. N., \& Latif, I. A. (2015). Factors influencing intention to adopt sustainable agriculture practices among paddy farmers in Kada, Malaysia. Asian Journal Agriculture Research, 9(5), 268-275. doi: 10.3923/ajar.2015. 268.275.

Zeweld, W., van Huylenbroeck, G., Tesfay, G., \& Speelman, S. (2017). Smallholder farmers' behavioral intentions towards sustainable agricultural practices Journal Environment Management, 187, 71-81.

Wiradmadja, I. (2017). Model Penerimaan Petani terhadap Teknologi Sistem Pertanian Organik di Kabupaten Tasikmalaya. Jurnal Manajemen Teknologi, 16(1), 81-91. doi:10.12695/ jmt.2017.16.1.6.

Dharmmesta, B. S. (2000). Perilaku Mencoba Beli: Sebuah Kajian Analitis Model Bagozzi Warshaw untuk Panduan Peneliti. Jurnal Ekonomi Dan Bisnis Indonesia, 12(3), 1- 27. 
Aikanathan, S., Chenayah, S., \& Sasekumar, A. (2011). Sustainable Agriculture: A Case Study On The Palm Oil Industry. Malaysia Journal Of Science, 30(1), 66-75.

[PASPI] Palm Oil Agribusiness Stategic Policy Institute. (2016). Mitos dan Fakta Industri Minyak Sawit Indonesia dalam Isu Sosial, Ekonomi dan Lingkungan Global. Bogor: PASPI. Available at:https://agroklimatologippks.files.wordpress.com/ 2016/02/mitosfakta. 